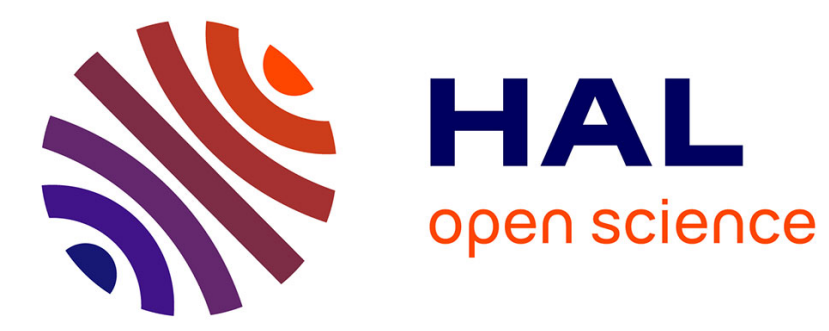

\title{
Reliable Determination of Ge in Solid Environmental Samples Using a Chemical Preparation Procedure Developed for Si Isotopes and ICP-MS Analysis
}

Camille Delvigne, Abel Guihou, Bernard Angeletti, Isabelle Basile-Doelsch, Jean-Dominique Meunier

\section{To cite this version:}

Camille Delvigne, Abel Guihou, Bernard Angeletti, Isabelle Basile-Doelsch, Jean-Dominique Meunier. Reliable Determination of Ge in Solid Environmental Samples Using a Chemical Preparation Procedure Developed for Si Isotopes and ICP-MS Analysis. Geostandards and Geoanalytical Research, 2018, 42 (1), pp.139 - 149. 10.1111/ggr.12197 . hal-01695926

\section{HAL Id: hal-01695926 \\ https://hal.science/hal-01695926}

Submitted on 18 May 2018

HAL is a multi-disciplinary open access archive for the deposit and dissemination of scientific research documents, whether they are published or not. The documents may come from teaching and research institutions in France or abroad, or from public or private research centers.
L'archive ouverte pluridisciplinaire HAL, est destinée au dépôt et à la diffusion de documents scientifiques de niveau recherche, publiés ou non, émanant des établissements d'enseignement et de recherche français ou étrangers, des laboratoires publics ou privés. 


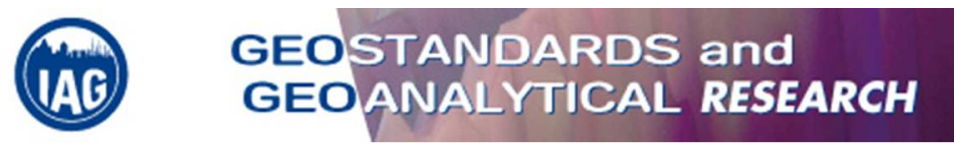

\section{Reliable determination of Ge using the silicon isotopes chemical preparation and ICP-MS analysis for solid environmental samples.}

\begin{tabular}{|r|l|}
\hline Journal: & Geostandards and Geoanalytical Research \\
\hline Manuscript ID & GGR-0514.R1 \\
\hline Manuscript Type: & Original Article \\
\hline Date Submitted by the Author: & n/a \\
\hline Complete List of Authors: & $\begin{array}{l}\text { Delvigne, Camille; Centre Europeen de Recherche et d'Enseignement des } \\
\text { Geosciences de I'Environnement, } \\
\text { Guihou, Abel; Centre Europeen de Recherche et d'Enseignement des } \\
\text { Geosciences de I'Environnement } \\
\text { Angeletti, Bernard; Centre Europeen de Recherche et d'Enseignement des } \\
\text { Geosciences de I'Environnement } \\
\text { Basile-Doelsch, Isabelle; Centre Europeen de Recherche et d'Enseignement } \\
\text { des Geosciences de I'Environnement } \\
\text { Meunier, Jean-Dominique; Centre Europeen de Recherche et } \\
\text { d'Enseignement des Geosciences de I'Environnement }\end{array}$ \\
\hline Keywords: & $\begin{array}{l}\text { germanium, ICP-MS, reference materials, soils, plants, sample digestion, } \\
\text { cation exchange purification }\end{array}$ \\
\hline
\end{tabular}


1

2

3

4

5

6

7

8

9

10

11

12

13

14

15

16

17

18

19

20

21

22

23

24

25

26

27

28

29

30

31

32

33

34

35

36

37

38

39

40

41

42

43

44

45

46

47

48

49

50

51

52

53

54

55

56

57

58

59

60

1 Reliable determination of Ge using the silicon isotopes chemical preparation and

2 ICP-MS analysis for solid environmental samples.

3

4

5 Camille Delvigne (1) *, Abel Guihou (1), Bernard Angeletti (1), Isabelle Basile-Doelsch (1), Jean-

6 Dominique Meunier (1)

7 (1) Aix-Marseille Univ, CNRS, IRD, Coll. de France, INRA, CEREGE, Europôle Mediterranéen de

8 l'Arbois BP 8013545 Aix-en-Provence, cedex 4, France

9

10

*Corresponding author. Email : delvigne@cerege.fr

11

12

13

14 Keywords: germanium, ICP-MS, reference materials, soils, plants, sample digestion, cation exchange

15 purification

16 Mots clés: germanium, ICP-MS, matériaux de référence, sols, plantes, digestion d'échantillon,

17 purification cationique par résine échangeuse d'ions

18 


\section{Abstract}

20 Germanium $(\mathrm{Ge})$ exists at trace levels in the Earth's crust and is a powerful geochemical tracer of the silicon (Si) cycle. This study proposes a simple and reliable method for

22 determining Ge contents in environmental samples using ICP-MS. As Si and Ge have very

23 similar chemical properties, we investigated the applicability of the chemical preparation

24 procedure developed for Si isotopes to the analysis of Ge in environmental samples.

25 Advantages of this procedure are: (1) efficient removal of the matrix and main interferences

26 affecting Ge analyses by ICP-MS; (2) a low limit of detection (6 $\left.\mathrm{ng}^{-1}\right)$; (3) relative

27 repeatability of approximately $3 \%$ obtained on ${ }^{74} \mathrm{Ge}$; and (4) robustness and accuracy based on agreement within errors with the published Ge concentrations for rock standards (BHVO2, AGV-2 and BCR-2). This procedure allows revising the Ge concentrations for 3 soils 30 standards $\left(1.67 \pm 0.09 \mu \mathrm{g} \mathrm{g}^{-1} ; 2.41 \pm 0.18 \mu \mathrm{g} \mathrm{g}^{-1} ; 1.89 \pm 0.10 \mu \mathrm{g} \mathrm{g}^{-1}\right.$ for GBW 07401, GBW 07404 31 and GBW 07407 respectively) and proposing a value for the ERM-CD281 plant standard

$32\left(0.06 \pm 0.01 \mu \mathrm{g} \mathrm{g}^{-1}\right)$. This method provides a convenient procedure for determining Ge concentrations in environmental samples and opens the possibility of coupling two tracers of the Si biogeochemical cycle with a single analytical procedure. 
36

37

38

39

40

41

42

43

44

45

46

47

48

49

50

51

52

53

Résumé

Le germanium $(\mathrm{Ge})$, présent à des teneurs en trace dans la croute terrestre, est un traceur géochimique performant du cycle du silicium (Si). Cette étude propose une méthode simple, rapide et fiable pour déterminer les concentrations en Ge dans les échantillons environnementaux par ICP-MS. Vu les propriétés géochimiques très similaires entre Ge et $\mathrm{Si}$, nous avons investigué la pertinence de la procédure de mise en solution et de purification développée pour les isotopes du silicium à l'analyse du Ge dans des échantillons environnementaux. Les avantages de cette technique sont : (1) une élimination efficace de la matrice et des interférences principales affectant l'analyse du Ge par ICP-MS ; (2) une limite de détection de $6 \mathrm{ng} \mathrm{l}^{-1}$; (3) une répétabilité relative de $3 \%$ obtenue sur l'isotope ${ }^{74} \mathrm{Ge}$; (4) une bonne fiabilité et justesse basées sur la concordance entre les valeurs de Ge publiées pour les standards de roche (BHVO-2, AGV-2 et BCR-2) aux incertitudes près. Cette méthode a permis de réévaluer les concentrations en Ge de 3 standards de sol $\left(1.67 \pm 0.09 \mu \mathrm{g} \mathrm{g}^{-1}\right.$; $2.41 \pm 0.18 \mu \mathrm{g} \mathrm{g}^{-1} ; 1.89 \pm 0.10 \mu \mathrm{g} \mathrm{g}^{-1}$ pour GBW 07401, GBW 07404 et GBW 07407 respectivement) et de proposer une valeur pour le standard de plante ERM-CD281 $(0.06 \pm 0.01$ $\left.\mu \mathrm{g} \mathrm{g}^{-1}\right)$. Cette méthode présente aussi le grand avantage de coupler deux traceurs du cycle du silicium (à savoir les isotopes stables du silicium et le rapport $\mathrm{Ge} / \mathrm{Si}$ ), en une préparation chimique unique. 


\section{Introduction}

Germanium $(\mathrm{Ge})$ exists at trace levels in the Earth's crust and is a powerful geochemical tracer of the silicon ( $\mathrm{Si}$ ) cycle. Like $\mathrm{Si}, \mathrm{Ge}$ is a Group IV element. Both elements have identical outer electronic configurations and similar covalent radii (Ge: $1.22 \AA$ and Si 1.17 Höll et al., 2007). The geochemistry of Ge is dominated by its propensity to substitute for Si in silicate minerals, and thus closely follows Si through its biogeochemical cycle.

Fundamentals of high and low-temperature geochemistry of Ge are reviewed in Rouxel and Luais (2017). To summarize, the Ge/Si ratio has been employed as a tracer of weathering processes (e.g., Kurtz and Derry, 2004; Scribner et al., 2006; Opfergelt et al., 2010; Lugolobi et al., 2010), hydrothermal and geothermal activity (e.g., Mortlock et al., 1993; Evans and Derry, 2002), biological processes (e.g., Ellwood and Maher, 2003; Derry et al., 2005; Sutton et al., 2010), and flow paths (e.g., Kurtz et al., 2011) in modern environments but also in paleo-environmental studies (e.g., Filippelli et al., 2000; Hammond et al., 2004). The use of Ge/Si has recently been extended to the study of the Archean Si cycle (e.g., Hamade et al., 2003; Frei and Polat, 2007; Delvigne et al., 2012; 2016). Another facet of Ge environmental research focuses on the potential economic resource of Ge in soils and plants as the Ge demand for new technologies is exploding while Ge is rare in natural environments (Rosenberg, 2009; Wiche et al., 2017). However, Ge content is often overlooked in the array of analyzed elements. This arises from the analytical difficulties to obtain reliable data because Ge concentrations in environmental samples are generally below the limit of detection of many modern analytical methods. In addition, Ge suffers from various interferences on its isotopes with ICP-MS techniques (mainly ${ }^{56} \mathrm{Fe}^{16} \mathrm{O}$ on ${ }^{72} \mathrm{Ge},{ }^{57} \mathrm{Fe}^{16} \mathrm{O}$ and ${ }^{56} \mathrm{FeH}^{16} \mathrm{O}$ on ${ }^{73} \mathrm{Ge}$, and ${ }^{74} \mathrm{Se}$ and ${ }^{58} \mathrm{Ni}^{16} \mathrm{O}$ on $\left.{ }^{74} \mathrm{Ge}\right)$. Interferences due to iron oxides are particularly problematic because some samples contain a few tenths of a percent of Fe while Ge is present at a $\mu \mathrm{g} \mathrm{g}^{-1}$ level. The ${ }^{58} \mathrm{Ni}^{16} \mathrm{O}$ interference is also an issue as it combines the 
most abundant $\mathrm{Ni}$ and $\mathrm{O}$ isotopes $\left({ }^{58} \mathrm{Ni}=68 \% ;{ }^{16} \mathrm{O}=99 \%\right)$. In addition, Ar-based molecular

80

81

82 interferences $\left({ }^{40} \mathrm{Ar}^{16} \mathrm{O}_{2},{ }^{36} \mathrm{Ar}^{36} \mathrm{Ar}\right.$ and ${ }^{38} \mathrm{Ar}^{36} \mathrm{Ar}$ on ${ }^{72} \mathrm{Ge},{ }^{73} \mathrm{Ge}$ and ${ }^{74} \mathrm{Ge}$, respectively) should also be monitored. Germanium is then often qualified as a "tricky" element to analyze and is not routinely determined in environmental samples.

The majority of studies published so far on Ge have been carried out using the isotopedilution hydride-generation ICP-MS technique (ID-HG-ICP-MS) developed by Mortlock and Froelich (1996) (Fillipelli et al., 2000; Kurtz et al., 2002; Evans and Derry, 2002; Derry et al., 2005; Wheat and McManus, 2005; Ellwood et al., 2006; Scribner et al., 2006; Blecker et al., 2007; Makishima and Nakamura, 2009; Lugolobi et al., 2010; Sutton et al., 2010). This is probably the most reliable and precise technique for Ge determination, although it requires a hydride generation system, which is not widespread in laboratories. Alternative techniques are: (1) graphite furnace atomic absorption spectrometry (GF-AAS) (McMahon et al., 2006); (2) ICP-MS analysis with or without high resolution (Hamade et al., 2003 ; Delvigne et al., 2009; Cornelis et al., 2010; Tribovillard et al., 2011); (3) laser ablation ICP-MS analysis (Hamade et al., 2003; Shen et al., 2011; Belissont et al., 2014; Dong et al., 2015;); and (4) Xray fluorescence spectrometer analysis (Frei and Polat, 2007). While valid for most geological samples, these techniques are working close to their limits of detection for environmental samples, such as plants that commonly range from 0.07 to $20 \mathrm{ng} \mathrm{g}^{-1}$ (Derry et al., 2005; Blecker et al., 2007; Delvigne et al., 2009; Cornelis et al., 2010; Lugolobi et al., 2010). One option is to preconcentrate samples in order to reach concentrations above the detection limits. This was investigated by Soylak and Yigit (2015), who suggested a separationpreconcentration procedure using a polysulfone membrane filter combined with spectrophotometric measurements. This method has the disadvantage of requiring specific materials. For natural water samples, ID-HG-ICP-MS remains the only reliable technique thanks to its high precision and unequaled low detection limits. 
104 The objective of this study is to propose a simple and reliable alternative method determining

105 Ge contents in solid environmental samples, with a notable focus on soils and plants using

106 ICP-MS, a common instrument found in geochemistry laboratories. As silicon isotopes and

$107 \mathrm{Ge} / \mathrm{Si}$ ratios are complementary tracers of the Si biogeochemical cycle, we investigate the

108 applicability of the chemical preparation procedure developed for silicon isotopes (Georg et

109 al., 2006) to the analysis of Ge in solid environmental samples.

110 2. Experimental

$111 \quad 2.1$ Material analyzed

112 Reference materials with the recommended values for Ge concentrations are scarce. Three

113 international geological USGS reference materials have been chosen in this study for

114 intercomparison with previous studies: BHVO-2 (basalt), AGV-2 (andesite), and BCR-2

115 (basalt). Despite certified values not being available for these standards, an increasing number

116 of published data provide constraints on Ge concentrations (Table 1). A considerable

117 compilation effort was undertaken by Jochum et al. (2016), which provides reference values

118 (or informative values) determined following ISO guidelines and IAG Certification Protocol

119 using data published between 1995 and 2015. In addition, to better fit the matrix of targeted

120 samples of soils and plants, we selected three soil standards from the Institute of Geophysical

121 and Geochemical Exploration (IGGE, Langfang, China) (GBW 07401, GBW 07404 and

122 GBW 07407, also known as GSS-1, GSS-4 and GSS-7) and a plant standard from European

123 Reference Material (ERM-CD281). Certified Ge concentrations are available for the soils

124 standards, but with low precision (Table 1), while no Ge data is provided for ERM-CD281.

125 Recently, additional data have been made available for GBW 07401-07408 standards (Liu et

126 al., 2014) (Table 1). 


\begin{tabular}{|c|c|c|c|c|c|c|}
\hline & Sample type & Provider & Published value & $\operatorname{rsd}(2 \sigma)$ & $\mathbf{n}$ & References \\
\hline \multirow[t]{3}{*}{ BHVO-2 } & basalt & USGS & $1.62 \pm 0.04 \mu \mathrm{g} \mathrm{g}^{-1}$ & $2 \%$ & 10 & Jochum et al., 2016 \\
\hline & & & $1.53 \mu \mathrm{g} \mathrm{g}^{-1}$ & $0.2 \%$ & n.s. & Escoube et al., 2012 \\
\hline & & & $1.59 \pm 0.04 \mu \mathrm{g} \mathrm{g}^{-1}$ & $3 \%$ & 3 & Scribner et al., 2006 \\
\hline AGV-2 & andesite & USGS & $1.20 \pm 0.08 \mu \mathrm{g} \mathrm{g}^{-1}$ & $7 \%$ & 6 & Jochum et al., 2016 \\
\hline BCR-2 & basalt & USGS & $1.46 \pm 0.26 \mu \mathrm{g} \mathrm{g}^{-1}$ & $18 \%$ & 6 & Jochum et al., 2016 \\
\hline \multirow[t]{2}{*}{ GBW 07401} & soil & IGGE & $1.50 \pm 0.04 \mu \mathrm{g} \mathrm{g}^{-1}$ & $3 \%$ & 6 & Liu et al., 2014 \\
\hline & & & $1.34 \pm 0.2 \mu \mathrm{g} \mathrm{g}^{-1}$ & $15 \% *$ & at least 8 & Wang et al., 2013 \\
\hline \multirow[t]{2}{*}{ GBW 07404} & soil & IGGE & $2.10 \pm 0.02 \mu \mathrm{g} \mathrm{g}^{-1}$ & $1 \%$ & 6 & Liu et al., 2014 \\
\hline & & & $1.9 \pm 0.3 \mu g^{-1}$ & $16 \% *$ & at least 8 & Wang et al., 2013 \\
\hline GBW 07407 & soil & IGGE & $1.6 \pm 0.3 \mu \mathrm{g} \mathrm{g}^{-1}$ & $19 \% *$ & at least 8 & Wang et al., 2013 \\
\hline ERM-CD281 & plant & ERM & no data & - & - & - \\
\hline
\end{tabular}

Table 1. Reference materials analyzed in this study with their Ge concentrations and associated uncertainties. Values in bold are certified values while others are informative values. * refers to an uncertainty of $3 \sigma$ instead of $2 \sigma ;$ n.s. $=$ not specified.

\subsection{Sample digestion}

Samples were digested following the procedure developed for silicon isotopes using a solid sodium hydroxide $(\mathrm{NaOH})$ flux (Georg et al., 2006). Between 10-20 mg (200 mg up to 600 mg for ERM-CD281, the plant standard) of powdered samples were weighed directly into silver crucibles after drying for at least $24 \mathrm{~h}$ at $105^{\circ} \mathrm{C}$. Prior to the fusion, calcination steps were carried out to ensure the combustion of organic matter into $\mathrm{CO}_{2}$. Calcinations were performed at $450^{\circ} \mathrm{C}$ with a $1 \mathrm{~h}$ stage at $250^{\circ} \mathrm{C}$ to ensure slow temperature increase. The $450^{\circ} \mathrm{C}$ calcination step lasted for at least 1 hour for soils, and $16 \mathrm{~h}$ for plants. In the case of plants, the total calcination procedure lasted at least $24 \mathrm{~h}$. Qi et al., (2011) showed that calcination at $600^{\circ} \mathrm{C}$ does not induce Ge loss. Ashes were mixed with approximately $200 \mathrm{mg}$ of $\mathrm{NaOH}$ and placed in a furnace at $720^{\circ} \mathrm{C}$ for 10 minutes. Fusion cakes were then allowed to dissolve overnight in ultrapure water with a brief ultrasonic bath to favor dissolution. Solutions were then quantitatively transferred into pre-cleaned HDPE bottles and acidified to $\mathrm{pH} \sim 2$ with $\mathrm{HNO}_{3}$. Due to the volatile behavior of $\mathrm{Ge}$ in the presence of halogens $\left(\mathrm{HCl}, \mathrm{HClO}_{4}\right)$, only 
$145 \mathrm{HNO}_{3}$ could be used (Luais, 2007; 2012). Acidification to $\mathrm{pH} 2$ was important for Fe-rich

146 samples to ensure a complete dissolution of Fe-oxides as well as ensuring a complete

147 recovery during the following cationic purification (Fitoussi et al., 2009). At this $\mathrm{pH}$, the

148 dominant $\mathrm{Ge}$ species is the $\mathrm{Ge}(\mathrm{OH})_{4}{ }^{0}$ form (Pokrovski and Schott, 1998).

To overcome matrix effects and various interferences, which are complex to correct for, purification of samples appears to be an ideal approach. Perhaps more importantly, the elimination of matrix elements prior to analysis allows a substantial reduction in the dilution factor, which is of great interest for samples with low Ge contents. In addition, performance of ICP-MS can be fully exploited, as the sampling interface and the ion optics are not deteriorated due to salt depositions. A cation-free solution was obtained by passing the solution through a cation exchange column. This allowed for testing of the resin used for germanium isotopes chemical preparation, AG50W-X8 (100-200 mesh in $\mathrm{H}^{+}$form; Bio-Rad) (Luais, 2007, 2012) using the column chemistry routine of silicon isotopes (Georg et al., 2006). Sample solutions were loaded on a Bio-Rad type column filled with $1.8 \mathrm{ml}$ of AG50W-X8 cation-exchange resin, pre-cleaned with several rinsing with $\mathrm{HCl}, \mathrm{HNO}_{3}$ as detailed in the study of Georg et al., (2006) (Table 2). Before loading the sample on the resin, ultrapure water was passed into the resin to remove acids (Georg et al., 2006). The matrix (sodium from fusion and other cations from the sample itself) was retained on the resin, while anionic and neutral species $\left(\right.$ e.g., $\mathrm{Ge}(\mathrm{OH})_{4}{ }^{0}$ and $\left.\mathrm{Si}(\mathrm{OH})_{4}{ }^{0}\right)$ passed through. To minimize the dilution due to elution, the sample volume was maximized (here $\sim 10 \mathrm{ml}$ of fused solution) while the volume of eluent was kept to a minimum of one resin bed volume $(\sim 2 \mathrm{ml})$ (Table 2). Since the Si and Ge species do not interact with the resin, the eluent is simply ultrapure water. Ge was collected in a $\sim 12 \mathrm{ml}$ cation-free solution. Recovered solutions were weighed to minimize uncertainties inherent to the imprecise volumes recovered. Regarding the 
170 removal of matrix element, $\mathrm{Na}$ is potentially the more difficult element to eliminate as it is the

171 most abundant and resin shows a weak relative selectivity for Na. To warrant a good

172 purification, resin is largely in excess based on expected resin capacity and fused sample

173 concentrations. Indeed, a $10 \mathrm{ml}$ fused solution (typically $0.5 \mathrm{meq}$ ) saturates the resin

174 approximately $15 \%$ of its exchange capacity. Complete removal of ambient cationic species

175 and especially problematic cations (i.e., Fe, Ni, Zn) and Na was checked with ICP-MS.

\begin{tabular}{lcc}
\hline \multicolumn{3}{l}{ BioRad AG50W-X8, $1.8 \mathrm{ml}$ resin bed } \\
\hline Separation stage & Solution matrix & Volume $(\mathrm{ml})$ \\
\hline Pre-cleaning & $3 \mathrm{~N} \mathrm{HCl}$ & $3 \mathrm{ml}$ \\
Pre-cleaning & $6 \mathrm{~N} \mathrm{HCl}$ & $3 \mathrm{ml}$ \\
Pre-cleaning & $7 \mathrm{~N} \mathrm{HNO}$ & $3 \mathrm{ml}$ \\
Pre-cleaning & $10 \mathrm{~N} \mathrm{HCl}$ & $3 \mathrm{ml}$ \\
Pre-cleaning & $6 \mathrm{~N} \mathrm{HCl}$ & $3 \mathrm{ml}$ \\
Pre-cleaning & $3 \mathrm{~N} \mathrm{HCl}$ & $3 \mathrm{ml}$ \\
Rinse & ultrapure water & $6 \mathrm{ml}$ \\
\hline Sample load & Acidified fused sample & $10 \mathrm{ml}$ \\
Elution & ultrapure water & $2 \mathrm{ml}$ \\
\hline \multicolumn{3}{c}{}
\end{tabular}

\section{7}

Table 2. Column chemistry routine of the preparation of a solid sample fused with $\mathrm{NaOH}$ flux adapted from Georg et al., 2006.

\subsection{Sample introduction and mass spectrometry}

Ge concentrations were measured using an ICP-MS Nexion 300X (Perkin Elmer) using a PFA nebulizer, a quartz cyclonic spray chamber and a SC-FAST DX-4 automated introduction system. Operating conditions are detailed in Table 3. A series of five standard solutions with different concentrations $\left(50,100,250,500,1000 \mathrm{ng} \mathrm{l}^{-1}\right)$ were used to calibrate Ge concentrations. These calibration solutions were made from single element Ge standard 1000 mg $1^{-1}$ solution (Chem Lab, Plasma HIQU, 2-5\% $\mathrm{HNO}_{3}$ ). To correct for instrumental drift, rhodium (Chem Lab, Plasma HIQU, 2-5\% $\mathrm{HNO}_{3}$ ) was introduced to sample solutions through a cross flow line injection resulting in a Rh concentration of $1.58 \mu \mathrm{g}^{-1}$ in the analyzed solution. Ge isotopes 72,73 and 74 were analyzed and provided consistent values, proving the 
189 robustness of the method. However, Ge contents were determined using the ${ }^{74} \mathrm{Ge}$ isotope, the 190 most abundant isotopes (36.28\%), given higher sensitivity and lower detection limits

191 compared to other isotopes. In the sequence, $400 \mathrm{ng}^{-1} \mathrm{Ge}$ standard solutions were measured 192 after every 15 samples to check for instrumental drift and evaluate reproducibility.

\begin{tabular}{|c|c|}
\hline Plasma power & $1600 \mathrm{~W}$ \\
\hline Torch & Quartz glass torch \\
\hline Plasma Ar gas flow rate & $151 \mathrm{~min}^{-1}$ \\
\hline Auxiliary Ar gas flow rate & $1.21 \mathrm{~min}^{-1}$ \\
\hline \multirow[t]{2}{*}{ Nebuliser Ar gas flow rate } & $0.95-1.051 \mathrm{~min}^{-1}$ \\
\hline & (optimized to minimize ${ }^{140} \mathrm{Ce}^{16} \mathrm{O}^{+} /{ }^{140} \mathrm{Ce}^{+}<0.025$ and ${ }^{70} \mathrm{Ce}^{++} /{ }^{140} \mathrm{Ce}^{+}<0.03$ ) \\
\hline Nebuliser & PFA $0.4 \mathrm{ml} \mathrm{min}^{-1}$ \\
\hline Spray chamber & cyclonic (quartz) \\
\hline Sample uptake rate & $0.337 \mathrm{ml} \mathrm{min}^{-1}$ \\
\hline Interfaces cones & Nickel \\
\hline Resolution & 700 \\
\hline Typical ${ }^{74}$ Ge sensitivity & $\sim 12000 \mathrm{cps} \mu \mathrm{g}^{-1} \mathrm{I}$ \\
\hline Typical ${ }^{103} \mathrm{Rh}$ sensitivity & $\sim 680000 \mathrm{cps}_{\mu \mathrm{g}^{-1} \mathrm{I}}$ \\
\hline
\end{tabular}

Table 3. Instrumental operating conditions for ICP-MS Nexion 300X

3. Results and discussion

As the dominant $\mathrm{Ge}$ species after fusion is the $\mathrm{Ge}(\mathrm{OH}){ }_{4}{ }^{0}$, no affinity for cation exchange resin procedure. A complete Ge recovery $(102 \pm 2 \% ; n=6)$ during sample purification through cationic resin was obtained with single element Ge standard solution at different Ge concentrations (330 to $1100 \mathrm{ng} \mathrm{l}^{-1}$; Fig. 1). To take into account matrix effects, recovery yields for BHVO-2 and GBW 07401 were determined by Ge standard addition to the fused solution before purification (Ge addition from $10 \mathrm{ng} \mathrm{l}^{-1}$ to $100 \mathrm{ng} \mathrm{l}^{-1}$; Fig. 1). The recovery yields for BHVO-2 (99 $\pm 2 \% ; n=4)$ indicated a complete recovery for Ge. In the case of GBW 07401 (Ge addition from $10 \mathrm{ng} \mathrm{l}^{-1}$ to $1000 \mathrm{ng} \mathrm{l}^{-1}$; Fig. 1), recoveries of approximately $118 \pm 5 \%$ $(n=6)$ were found when compared to the certified value (Wang et al., 2013). Considering the 
207 Ge concentrations of Liu et al., (2014), who suggested that the Ge concentration of this

208 standard should be revised, our recovery yield was $109 \pm 2 \%$ (Fig. 1). As the procedural blanks

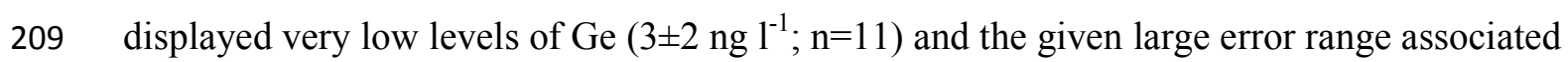

210 with the certified value of this standard (Table 1), we assume our recovery for this standard to

211 be complete. A better agreement would require refining the reference value for the GBW

21207401 standard (see section 3.2). Based on single element Ge standard solution and BHVO-2,

213 we assume that Ge recovery is complete during cationic purification. The standard addition of

214 BHVO-2 and GBW 07401 show that Si and other neutral, as well as anionic species do not

215 create any matrix effect.

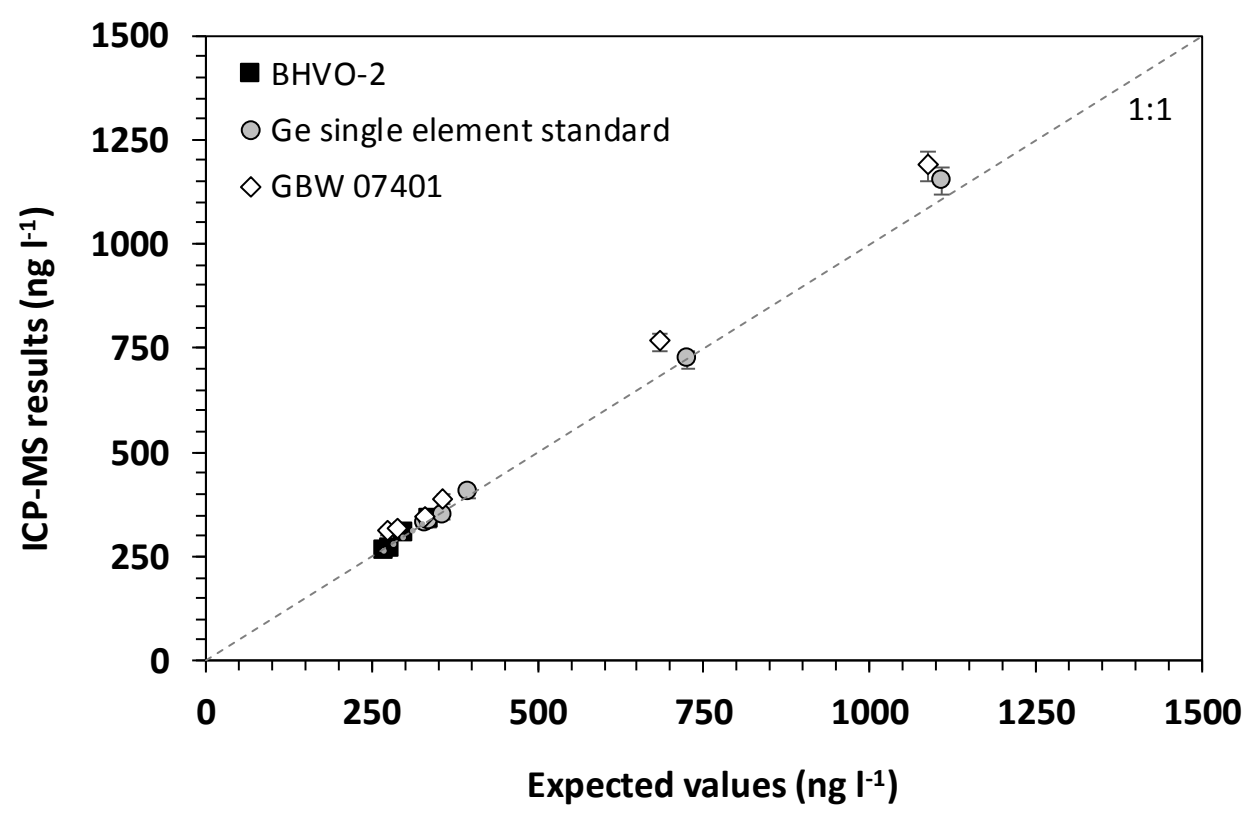

217 Fig. 1 Comparison of the Ge concentrations obtained by ICP-MS after cationic purification

218 and expected values for single element Ge standard solution at various Ge concentrations

219 (gray circles) and reference materials (BHVO-2, black squares; GBW 07401, open diamonds)

220 with Ge standard addition (Ge addition from $10 \mathrm{ng} \mathrm{l}^{-1}$ to $1000 \mathrm{ng} \mathrm{l}^{-1}$ ). The dashed gray line

221 represents a recovery yield of 100\%. Expected values for reference materials are calculated 
222 considering Ge data from the literature (Escoube et al., 2012; Scribner et al., 2006 and Liu et al., 2014, see section 3.2). Error bars represent the analytical repeatability (3\%).

224

225

226
229

The separation efficiency is demonstrated by the elution curves of two samples (a single element Ge standard solution and a fused BHVO-2) that were loaded onto the pre-cleaned cation exchange resins (Fig. 2). Ge is not retained by the resin and migrates straight through the column and nearly $90 \%$ of the loaded Ge is already recovered while the sample load is still infiltrating the resin bed. The last $10 \%$ is recovered with $2 \mathrm{ml}$ of ultrapure water (Fig. 2).

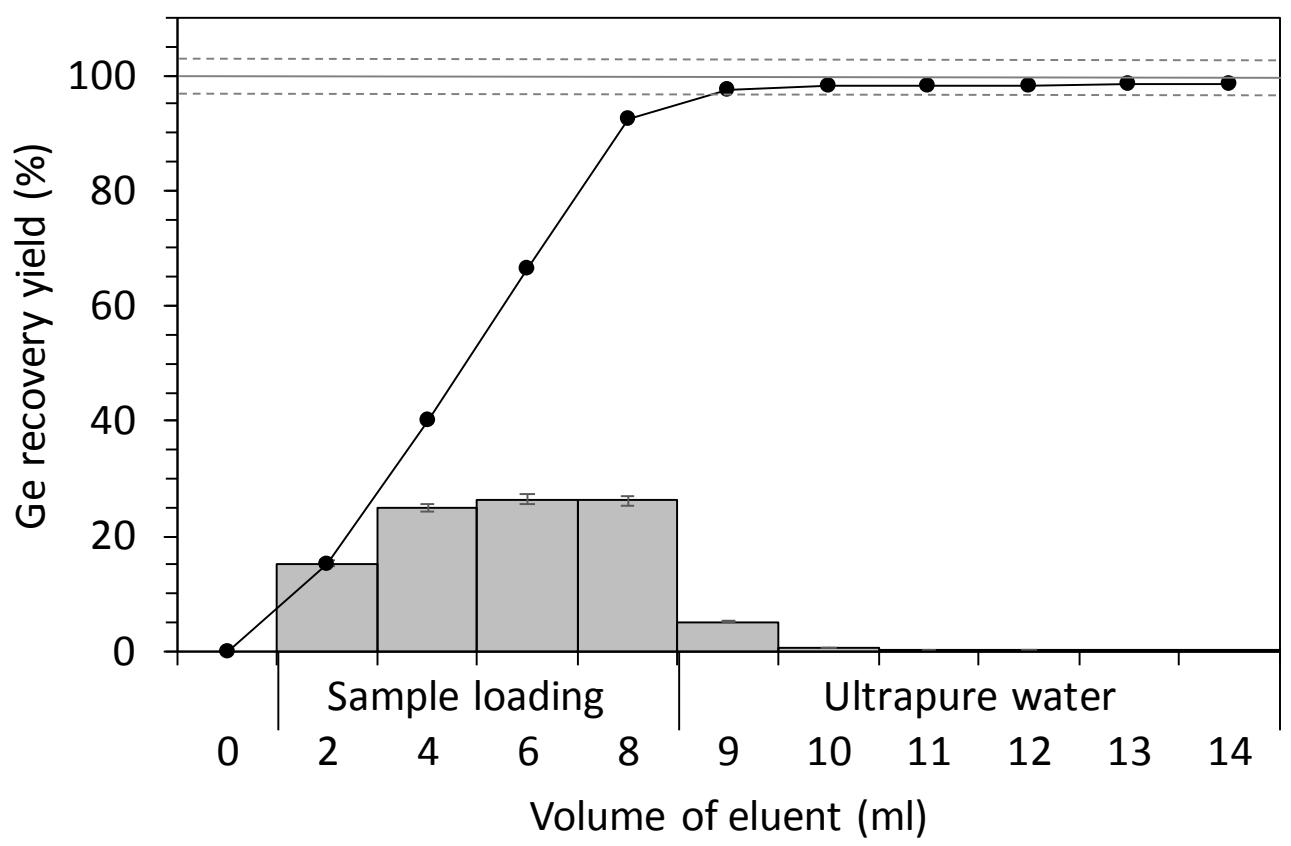

Fig. 2 Elution of germanium during chemical purification of BHVO-2 on AG50W-X8 resin. The black circles corresponds to the cumulated Ge recovered whereas grey bars represent $\mathrm{Ge}$ recovered in each volume loaded. Error bars represent the analytical repeatability. Furthermore, ICP-MS screening of the purified solution confirms the absence of major cations and interfering cations after purification (Fig. 3). As demonstrated for Si by Georg et al., (2006), this shows a complete separation of Ge from the ambient cation matrix. Matrix effects and interferences are then negligible and should not be corrected for, minimizing the errors in Ge contents. In addition, Ar-based molecular interferences are not detectable in the blanks. 


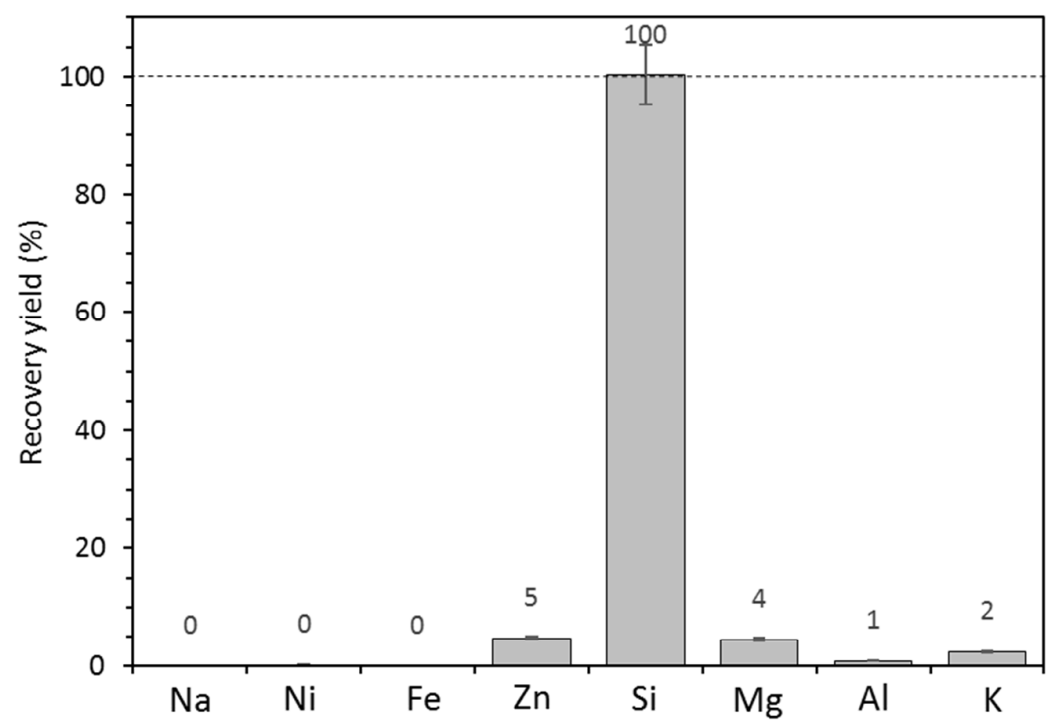

Fig. 3. Recovery yields of the main matrix elements and interfering elements of $\mathrm{NaOH}$ fused BHVO-2 after purification with AG50W-X8 resin.

242 Besides overcoming matrix effects and interferences, cationic purification has the advantage

243 to minimize the dilution for analysis, as samples are salt-free. Indeed, the above described

sample purification resulted in a dilution of the sample by a factor of 1.2. This is far less than

245 the dilution necessary to reduce total dissolved salt to the maximum of $0.1 \%$ accepted for

ICP-MS analysis (a dilution by a factor 2 being the minimum). However, some samples with

low Ge content might still be close to the detection limit. To overcome this issue, a

preconcentration step is helpful. A preconcentration step through low temperature evaporation was feasible, as solutions were free of major elements, limiting the risk of precipitation. For samples that might be close to detection limits, typically plants, an evaporation step at $60^{\circ} \mathrm{C}$ on a hotplate was performed to increase Ge concentrations. In this study, a maximal preconcentration factor of 2 was achieved without any modification of Ge recoveries. Indeed, 


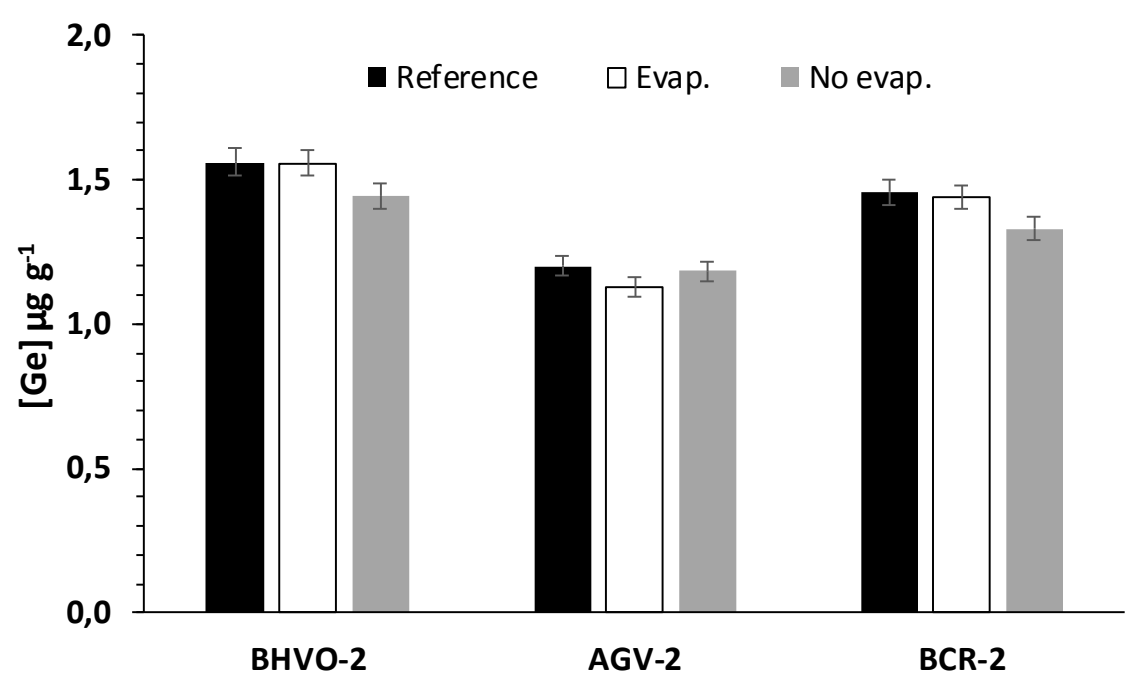

255

256

257

258

259

260

261

262

263

264

265

266

267

268

269

270

271

Fig. 4 Ge contents in reference materials (black; Escoube et al., 2012; Scribner et al., 2006;

Jochum et al., 2016) compared to ICP-MS Ge contents obtained using our preparation protocol, with (white) or without a final evaporation step (gray). Error bars on our results represent an uncertainty of 3\%, the ICP-MS analytical repeatability.

\subsection{Detection limits, repeatability and accuracy}

The contribution of Ge from the whole procedural chemistry blank was measured on 11 procedural blanks and has been found to be $3 \pm 2 \mathrm{ng}^{-1}$ and indistinguishable from the instrumental blank. According to the IUPAC definition (IUPAC, 1997), method detection limits were calculated as the mean concentration of 11 procedural blanks plus three standard deviations of these 11 procedural blanks (Table 4). The lowest detection limit was obtained for ${ }^{74} \mathrm{Ge}\left(6 \mathrm{ng} \mathrm{l^{-1 }}\right)$, the most abundant Ge isotope. For comparison, the detection limit for ${ }^{72} \mathrm{Ge}$ is 5 times higher, approximately $30 \mathrm{ng}^{-1}$ most likely due to the $\mathrm{ArO}_{2}$ interference.

Considering that $20 \mathrm{mg}$ of powdered sample was dissolved in $100 \mathrm{ml}$, this corresponds to a detection limit of approximately $0.03 \mu \mathrm{g} \mathrm{g}^{-1}$ in the solid sample (Table 4). For the plant standard (200-600 mg dissolved in $100 \mathrm{ml})$, the detection limit is approximately $0.001 \mu \mathrm{g} \mathrm{g}^{-1}$ in the solid sample. Additionally, the linearity limit was demonstrated over the entire 
272 calibration range. The linearity limit was above $1000 \mathrm{ng}^{-1}$, the highest standard in the

273 calibration curve, as the coefficient correlation of the calibration curve is above 0.995 .

\begin{tabular}{|c|c|c|c|c|c|c|c|c|}
\hline Method & Dissolution & Preliminary steps & $\begin{array}{c}\text { DL in } \\
\text { solution }\end{array}$ & $\begin{array}{l}\text { DL in solid } \\
\text { samples }\end{array}$ & Reproducibility & $\begin{array}{l}\text { Difference with } \\
\text { previously } \\
\text { published values }\end{array}$ & Samples & References \\
\hline ID-HG-ICP-MS & acid & ID & $0.5 \mathrm{ng} \mathrm{I}^{-1 \mathrm{a}}$ & - & $<3 \%$ & n.s. & natural waters & Evans and Derry, 2002 \\
\hline HR-ICP-MS & fusion & - & $10 \mathrm{ng} \mathrm{l}^{-1}$ & n.s. & $4 \%$ & n.s. & plants and soils & Delvigne et al., 2009 \\
\hline ICP-MS & fusion & - & $2 n g l^{-1}$ & $0.05 \mu \mathrm{g} \mathrm{g}^{-1}$ & $15 \%$ & n.s. & plants and soils & Cornelis et al., 2010 \\
\hline LA-ICP-MS & - & - & - & $<1 \mu \mathrm{g} \mathrm{g}^{-1}$ & $8 \%^{\mathrm{b}}$ & n.s. & rocks & Belissont et al., 2011; Shen et al., 2011 \\
\hline X-ray fluorescence & - & - & - & $1.5 \mu \mathrm{g} \mathrm{g}^{-1 \mathrm{c}}$ & $1 \%$ & $15 \%$ & rocks & Frei and Polat, 2007 \\
\hline Spectrophotometry & acid & $\begin{array}{l}\text { Polysulfone } \\
\text { membrane filter }\end{array}$ & $2 \mathrm{ng}^{-1}$ & n.s. & $5 \%$ & n.s. & waters and soils & Soylak and Yigit, 2015 \\
\hline ICP-MS & fusion & $\begin{array}{l}\text { Cationic } \\
\text { purification }\end{array}$ & $6 \mathrm{ng} \mathrm{I}^{-1}$ & $0.03 \mu \mathrm{g} \mathrm{g}^{-1}$ & $3 \%$ & $6 \%$ & plants, soils, rocks & This study \\
\hline
\end{tabular}

blank level

${ }^{\mathrm{b}}$ valid for $\mathrm{Ge} / \mathrm{Si}$ ratio as detailed in Shen et al., 2011

${ }^{c}$ minimum Ge concentration analyzed (no limit of detection provided)

\section{Table 4. Comparison of metrological characteristics of different techniques used for Ge}

\section{The relative repeatability of ICP-MS analysis based on a Ge single element standard solution} $\left(400 \mathrm{ng}^{-1}\right)$ and analyzed six times on a single day is $3 \%(\mathrm{n}=6$, confidence level $95 \%)$.

Similarly, four aliquots of one fused solution (BHVO-2) passed through four different columns and analyzed twice on the same day gives a relative repeatability of $2 \%$.

Reference materials of different composition (BHVO-2; AGV-2; BCR-2; GBW 07401; GBW 07404; GBW 07407) were analyzed to evaluate the accuracy of results (Supplementary Table 1). However, the absence of properly certified Ge values complicated the exercise. As shown in Fig. 5, our BHVO-2 data agree within $10 \%$ with the published value from the compilation of Jochum et al. (2016) (Table 5). However, a careful sorting of compiled data reveals that most of the dissolution protocols are not adapted to Ge, except for that of Scribner et al. (2006). Indeed, all but one of the studies employed acid attacks using $\mathrm{HCl}, \mathrm{HClO}_{4}$ or $\mathrm{HF}$ (at temperature above $60^{\circ} \mathrm{C}$ ) or a combination of these, which induce loss of Ge (Luais et al., 2012). Tests performed by Luais (2012) demonstrated that Ge loss is at $85 \%$ when $\mathrm{HClO}_{4}$ is employed in the acid dissolution mixture. In addition, it is unclear if ICP-MS analysis were corrected for spectroscopic interferences and selected Ge isotopes were not specified. Thus, 
292 Ge might be underestimated due to potential Ge volatilization during dissolution, while

293 uncorrected interferences would overestimate Ge content. In the literature, Ge contents

294 estimated using specific techniques devoted to Ge analysis (ID-HG-ICP-MS or double-spike

295 MC-ICP-MS) appear to be systematically lower than Ge contents estimated with ICP-MS

296 techniques. In the case of BHVO-2, ID-HG-ICP-MS and double spike MC-ICP-MS

297 techniques provided a compiled value of $1.56 \pm 0.07 \mu \mathrm{g} \mathrm{g}^{-1}$ (Table 5; Scribner et al., 2006;

298 Escoube et al., 2012), while ICP-MS techniques (acid attacks and interferences corrections

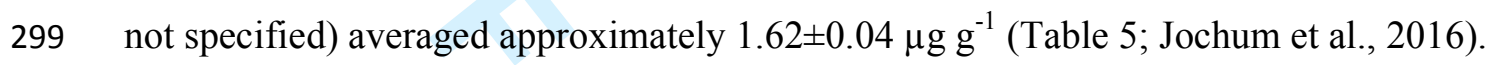

300 Similarly, BHVO-1 data show a comparable shift between the two techniques $(1.46 \pm 0.12 \mu \mathrm{g}$

$301 \mathrm{~g}^{-1}, \mathrm{n}=2$ for ID-HG-ICP-MS and double spike MC-ICP-MS; $1.64 \pm 0.06 \mu \mathrm{g} \mathrm{g}^{-1}, \mathrm{n}=3$ for ICP-

302 MS; Jochum et al., 2016). An intermediate Ge content $\left(1.58 \mu \mathrm{g} \mathrm{g}^{-1}\right)$ is obtained by Luais

303 (2012) using dedicated acid attack removing 80\% of matrix analyzed by ICP-MS suggesting

304 that discrepancy between techniques is likely induced by matrix and interferences. Despite

305 being more limited in number, data acquired using isotope dilution techniques are the most

306 robust (Escoube et al., 2012; Scribner et al., 2006). Considering the compiled values from

307 these two studies, our BHVO-2 results agree within 6\% (Fig. 5, Table 5). 
Regarding the other rock standards (AGV-2 and BCR-2), there is a better agreement between our data and the compiled data from Jochum et al., (2016) (Table 5). Considering these three rock standards, our data agree within $\sim 5 \%$ with published values.

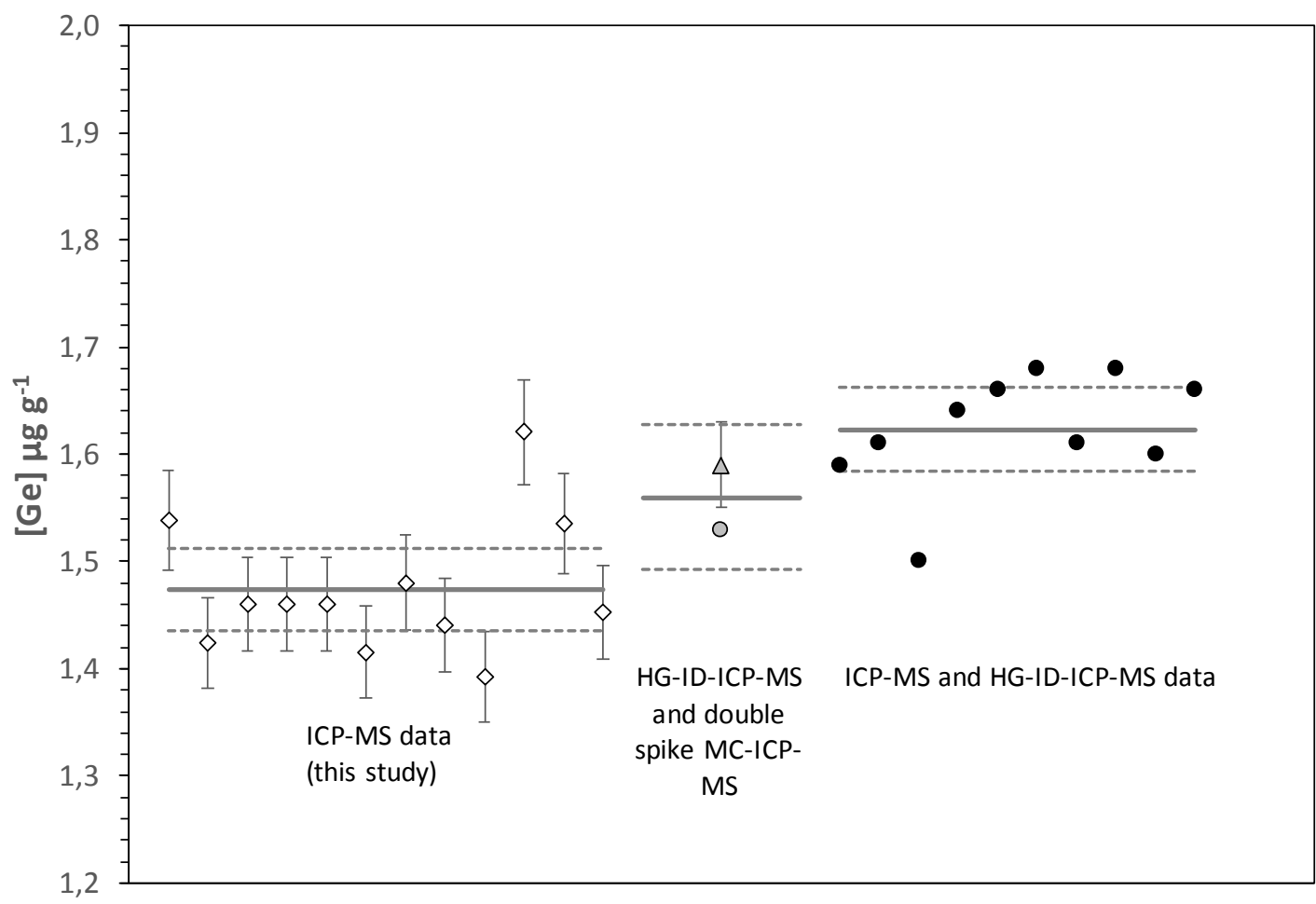

Fig. 5 Ge content in BHVO-2 from our study (open diamonds), high quality data (gray symbols) from Escoube et al. (2012) (gray circle; double spike MC-ICP-MS), and Scribner et al. 2006 (gray triangle; ID-HG-ICP-MS), compiled data from Jochum et al. 2016 (filled circles; ICP-MS and one ID-HG-ICP-MS from Scribner et al., 2006). Bold and dashed lines represent the mean and uncertainties (95\% confidence level) of each subgroup, respectively. Errors bars represent the analytical precision when provided (i.e., the $3 \%$ repeatability in this study).

Regarding soil standards (GBW 07401, 07404, 07407), our results are systematically 20 to $30 \%$ higher than certified values provided in Wang et al. (2013). However, a better agreement is noted when compared to data from Liu et al. (2014), suggesting that certified values should 
322 be revised. The use of $\mathrm{HClO}_{4}$ in the sample decomposition procedure calls into question the

323 accuracy of these data and may explain our systematically higher Ge contents.

\begin{tabular}{|c|c|c|c|c|c|c|c|c|}
\hline & Sample type & Ge value (this study) & $\mathrm{n}$ & $\begin{array}{l}\text { Difference with } \\
\text { published values }\end{array}$ & Published values & $\mathbf{n}$ & Technique & References \\
\hline \multirow[b]{2}{*}{ BHVO-2 } & \multirow[b]{2}{*}{ basalt } & \multirow[b]{2}{*}{$1.47 \pm 0.04 \mu \mathrm{g} \mathrm{g}^{-1}$} & \multirow[b]{2}{*}{11} & $9 \%$ & $1.62 \pm 0.04 \mu \mathrm{g} \mathrm{g}^{-1}$ & 10 & ICP-MS but one & Jochum et al., 2016 \\
\hline & & & & $8 \%$ & $1.56 \pm 0.04 \mu \mathrm{g} \mathrm{g}^{-1 \mathrm{a}}$ & 3 & $\begin{array}{l}\text { ID-HG-ICP-MS and } \\
\text { double spike MC-ICP-MS }\end{array}$ & $\begin{array}{l}\text { Scribner et al., } 2006 \text { and } \\
\text { Escoube et al. } 2012\end{array}$ \\
\hline AGV-2 & andesite & $1.14 \pm 0.08 \mu \mathrm{g} \mathrm{g}^{-1}$ & 6 & $5 \%$ & $1.20 \pm 0.08 \mu \mathrm{g} \mathrm{g}^{-1}$ & 6 & ICP-MS & Jochum et al., 2016 \\
\hline BCR-2 & basalt & $1.43 \pm 0.14 \mu \mathrm{g} \mathrm{g}^{-1}$ & 5 & $2 \%$ & $1.46 \pm 0.26 \mu \mathrm{g} \mathrm{g}^{-1}$ & 6 & ICP-MS but one & Jochum et al., 2016 \\
\hline \multirow{2}{*}{ GBW 07401} & \multirow{2}{*}{ soil } & \multirow{2}{*}{$1.67 \pm 0.09 \mu \mathrm{g} \mathrm{g}^{-1}$} & \multirow{2}{*}{11} & $11 \%$ & $1.50 \pm 0.04 \mu \mathrm{g} \mathrm{g}^{-1}$ & 6 & ICP-MS & Liu et al., 2014 \\
\hline & & & & $25 \%$ & $1.34 \pm 0.2 \mu \mathrm{g} \mathrm{g}^{-1}$ & at least 8 & n.s. & Wang et al., 2013 \\
\hline \multirow{2}{*}{ GBW 07404} & \multirow{2}{*}{ soil } & \multirow{2}{*}{$2.41 \pm 0.18 \mu \mathrm{g} \mathrm{g}^{-1}$} & \multirow{2}{*}{4} & $15 \%$ & $2.10 \pm 0.02 \mu \mathrm{g} \mathrm{g}^{-1}$ & 6 & ICP-MS & Liu et al., 2014 \\
\hline & & & & $27 \%$ & $1.9 \pm 0.3 \mu \mathrm{g} \mathrm{g}^{-1}$ & at least 8 & n.s. & Wang et al., 2013 \\
\hline GBW 07407 & soil & $1.89 \pm 0.10 \mu \mathrm{g} \mathrm{g}^{-1}$ & 3 & $18 \%$ & $1.6 \pm 0.3 \mu \mathrm{g} \mathrm{g}^{-1}$ & at least 8 & n.s. & Wang et al., 2013 \\
\hline ERM-CD281 & plant & $70 \pm 3 \mathrm{ng} \mathrm{g}^{-1}$ & 9 & & & & ICP-MS & This study \\
\hline
\end{tabular}

325

326

327

328

329

330

331

332

333

334

335

336

337

338

339

340

Table 5. Comparison of Ge contents in different reference materials between this study and data from the literature. n.s. $=$ not specified. Uncertainties are provided with $95 \%$ confidence level.

To provide the first Ge data on a plant standard, the standard ERM-CD281 was analyzed. Its Ge content is estimated to be approximately $70 \pm 3 \mathrm{ng} \mathrm{g}^{-1}(\mathrm{n}=9$; Supplementary Table 1).

\subsection{Perspectives}

This method provides a convenient procedure for determining accurate and precise Ge concentrations in rocks, soils and plants. Additionally, the combination of Ge concentrations with $\delta^{30} \mathrm{Si}$ analyses is the great advantage of this method, as both Si cycle tracers can be analyzed from a single procedure allowing a better understanding of the continental Si cycle. As emphasized in Cornelis et al. (2011), the combination of $\mathrm{Ge} / \mathrm{Si}$ ratios and silicon isotopes turned out to be a great asset for tracing the sources and fate of Si in the critical zone, where numerous co-occurring processes are difficult to decipher.

The method can likely be expanded to water samples under the condition of respecting the detection limits. The purification step of this procedure would then be suitable for hydrothermal fluids (12 $\pm 13 \mu \mathrm{g} 1^{-1}$ up to $50 \mu \mathrm{g} \mathrm{l^{-1 }}$; Evans and Derry, 2002) and soil solutions 
341 (7.1 $\pm 1.4 \mu_{\mathrm{g} \mathrm{l}}{ }^{-1}$; Cornelis et al., 2010). However, the analysis of silicon isotopes on the same

342 chemical preparation may not be straightforward because of DOC and anions responsible for 343 isotopic bias (Hughes et al., 2011). Water samples with lower Ge contents, such as freshwater 344 and seawater, might be pre-concentrated using Mg-coprecipation (Escoube, 2008). As many 345 other elements are scavenged by this method, the Mg-coprecipitation should be followed by 346 the cationic purification step. As both Ge and Si recoveries are complete during Mg347 coprecipitation (Escoube, 2008; Cardinal et al., 2005), the analysis of silicon isotopes and Ge 348 concentrations could again be performed on the same preparation. However, as anionic 349 species will not be removed completely, care should be taken to control the bias induced by 350 anionic species on $\delta^{30} \mathrm{Si}$ analysis (Hughes et al., 2011). In addition to silicon isotopes analysis, this method paves the way towards a new approach to

352 perform Ge isotopes is soils and plants, which has never been done before. Combining silicon 353 isotopes, germanium isotopes and $\mathrm{Ge} / \mathrm{Si}$ ratios would be a powerful multi-proxy approach to 354 tackle continental Si biogeochemical cycle.

\section{Conclusions}

The fusion and purification technique based on the Si isotopes preparation protocol (Georg et al., 2006) allows precise determination of Ge concentrations in environmental samples down to a detection limit of approximately $6 \mathrm{ng} \mathrm{l}^{-1}$. Analyses performed on ${ }^{74} \mathrm{Ge}$, the most abundant isotope, show the best precision of approximately $3 \%$. Accuracy, difficult to assess given the scarcity of reliable data available for comparison, was assessed with an error of approximately $5 \%$. This method provides data with equivalent or better metrological characteristics than other published procedures and analytical techniques except for ID-HG-ICP-MS, which shows the best precision and lowest detection limit (Table 4) but is much more time consuming. In addition to the reliability of generated data, this technique has two major 
365 advantages: (1) it does not require peculiar instruments such a hydride generation system, not

366 found in most laboratories unless specific needs, and (2) Ge concentrations and Si isotopic

367 analysis can be performed on the same solution. This last point represents a precious gain of

368 time in terms of sample preparation as one procedure serves to perform both analyses. A

369 systematic coupling of $\mathrm{Ge} / \mathrm{Si}$ ratios and $\delta^{30} \mathrm{Si}$ compositions is a great asset in the interpretation

370 of the Si cycle, as both tracers are very complementary.

371 Acknowledgments

372 This study has been funded by the ANR project BIOSiSOL (ANR-14-CE01-002). The French

373 Agence Nationale de la Recherche supported the study through the Project EQUIPEX

374 ASTER-CEREGE. Authors thank Hélène Mariot for her management of the clean laboratory.

375

376

377

378

379

380

381

382

383

384

385

386

\section{References}

Blecker S.W., King S. L., Derry L.A., Chadwick O.A., Ippolito J.A. and Kelly E.F. (2007) The ratio of germanium to silicon in plant phytoliths: quantification of biological discrimination under controlled experimental conditions. Biogeochemistry, 86,189-199.

Belissont R., Boiron M.-C., Luais B. and Cathelineau M. (2014) LA-ICP-MS analyses of minor and trace elements and bulk Ge isotopes in zoned Ge-rich sphalerites from the Noailhac - Saint-Salvy deposit (France): Insights into incorporation mechanisms and ore deposition processes. Geochimica et Cosmochimica Acta 126, 518-540.

Cardinal D., Alleman L. Y., Dehairs F., Savoye N., Trull T.W., André L. (2005) Relevance of silicon isotopes to Si-nutrient utilization and Si-source assessment in Antarctic waters. Global Biogeochemical cycles, 19, GB2007, doi:10.1029/2004GB002364. 
387 Cornelis J.-T., Delvaux B., Cardinal D., André L., Ranger J., Opfergelt S. (2010). Tracing

388

389

390

391

392

393

394

395

396

397

398

399

400

401

402

403

404

405

406

407

408

409 mechanisms controlling the release of dissolved silicon in forest soil solutions using $\mathrm{Si}$ isotopes and Ge/Si ratios. Geochimica et Cosmochimica Acta 74 (2010) 3913-3924.

Cornelis J.-T., Delvaux B., Georg R. B., Lucas Y., Ranger J., Opfergelt S. (2011) Tracing the origin of dissolved silicon transferred from various soil-plant systems towards rivers: a review. Biogeosciences, 8, 89-112.

Delvigne C., Opfergelt S. , Cardinal D., Delvaux B. and André L. (2009) Distinct silicon and germanium pathways in the soil-plant system: Evidence from banana and horsetail. Journal of Geophysical Research, 114, G02013, doi:10.1029/2008JG000899.

Delvigne, C., Cardinal, D., Hofmann, A., André, L., (2012) Stratigraphic changes of Ge/Si, $\mathrm{REE}+\mathrm{Y}$ and silicon isotopes as insights into the deposition of a Mesoarchaean banded iron formation. Earth and Planetary Science Letters, 355-356, 109-118.

Delvigne C., Opfergelt S., Cardinal D., Hofmann A. and André, L., (2016) Desilication in Archean weathering processes traced by silicon isotopes and $\mathrm{Ge} / \mathrm{Si}$ ratios. Chemical Geology, 420, 139-147.

Derry L.A., Kurtz A. C., Ziegler K., and Chadwick O. A. (2005) Biological control of terrestrial silica cycling and export fluxes to watersheds. Nature, 433, 728-731.

Dong L., Shen B., Lee C.-T. A., Shu X.-J., Peng Y., Sun Y., Tang Z., Rong H., Lang X., Ma H., Yang F. and Guo W. (2015) Germanium/silicon of the Ediacaran-Cambrian Laobao cherts: Implications for the bedded chert formation and paleoenvironment interpretations. Geochemistry, Geophysics, Geosystems, 16, 751-763, doi:10.1002/2014GC005595.

Ellwood M.J., Kelly M., Maher W. A. and De Deckker P. (2006) Germanium incorporation into sponge spicules: Development of a proxy for reconstructing inorganic germanium 
410

411

412

413

414

415

416

417

418

419

420

421

422

423

424

425

426

427

428

429

430

and silicon concentrations in seawater. Earth and Planetary Science Letters, 243, 749759.

Ellwood M.J. and Maher W.A. (2003) Germanium cycling in the waters across a frontal zone: the Chatham Rise. New Zealand, Marine Chemistry 80, 145- 159.

Evans M. J. and Derry L.A. (2002) Quartz control of high germanium/silicon ratios in geothermal waters. Geology, 30, 1019-1022.

Escoube R. (2008) Iron and germanium isotope geochemistry in river and hydrothermal systems. PhD Thesis, Université de Pau et des pays de l'Adour, 275 pages.

Escoube R., Rouxel O. J., Luais B., Ponzevera E. and Donard O. F.X. (2012) An Intercomparison Study of the Germanium Isotope Composition of Geological Reference Materials. Geostandards and Geoanalytical Research, 36, 149-159.

Filippelli G.M., Carnahan J.W., Derry L.A., and Kurtz A. (2000) Terrestrial paleorecords of Ge/Si cycling derived from lake diatoms. Chemical Geology, 168, 9-26.

Frei R. and Polat A. (2007) Source heterogeneity for the major components of $\sim 3.7 \mathrm{Ga}$ Banded Iron Formations (Isua Greenstone Belt, Western Greenland): Tracing the nature of interacting water masses in BIF formation. Earth and Planetary Science Letters, 253, $266-281$.

Fitoussi C., Bourdon B., Kleine T., Oberli F. and Reynolds B. C. (2009) Si isotope systematics of meteorites and terrestrial peridotites: implications for $\mathrm{Mg} / \mathrm{Si}$ fractionation in the solar nebula and for Si in the Earth's core. Earth and Planetary Science Letters, $287,77-85$. 
431 Georg R.B., Reynolds B.C., Frank M. and Halliday A.N. (2006) New sample preparation

432 techniques for the determination of Si isotopic compositions using MC-ICPMS. Chemical

433 Geology, 235, 95-104.

434 Hamade T., Konhauser K., Raiswell R., Goldsmith S. and Morris R. (2003) Using Ge/Si

435 ratios to decouple iron and silica fluxes in Precambrian banded iron formations. Geology,

$436 \quad 31,35-38$.

437 Hammond D. E., McManus J. and Berelson W. M. (2004) Oceanic germanium/silicon ratios:

438 Evaluation of the potential overprint of temperature on weathering signals.

439 Paleoceanograpy, 19, doi/10.1029/2003PA000940.

440 Hughes H.H., Delvigne C., Korntheuer M., de Jong J., André L. and Cardinal D. (2011)

441 Controlling the mass bias introduced by anionic and organic matrices in silicon isotopic

442 measurements by MC-ICP-MS. Journal of Analytical Atomic Spectrometry, 26, 1892-

$443 \quad 1896$.

444 Höll R., Kling M. and Schroll E. (2007) Metallogenesis of germanium-A review. Ore $445 \quad$ Geology Reviews, 30, 145-180.

446 IUPAC (1997). Compendium of Chemical Terminology, 2nd ed. (the "Gold Book").

447 Compiled by A. D. McNaught and A. Wilkinson. Blackwell Scientific Publications, $448 \quad$ Oxford.

449 Jochum K.P., Weis U., Schwager B., Stoll B., Wilson S.A., Haug G.H., Andreae M.O. and

450 Enzweiler J. (2016) Reference Values Following ISO Guidelines for Frequently

451 Requested Rock Reference Materials. Geostandards and Geoanalytical Research, 40,

$452 \quad 333-350$. 
453 Kurtz A.C., Lugolobi F., and Salvucci G. (2011) Germanium-silicon as a flow path tracer:

454 Application to the Rio Icacos watershed. Water Resources Research, 47, W06516, 455 doi: $10.1029 / 2010$ WR009853, 2011

456 Kurtz A. C., Derry L. A., and Chadwick O. A. (2002) Germanium-silicon fractionation in the 457 weathering environment. Geochimica et Cosmochimica Acta, 66, 1525-1537.

458 Kurtz A. C. and Derry L. A. (2004) Tracing silicate weathering and terrestrial silica cycling 459 with Ge/Si ratios. In Wanty, R. B. and Seal, R. R., editors, Proc. 11th Int. Symp. on 460 Water Rock Interaction, 833-836, The Netherlands.Balkema Pubs.

461 Luais B. (2007) Isotopic fractionation of germanium in iron meteorites: Significance for 462 nebular condensation, core formation and impact processes. Earth and Planetary Science $463 \quad$ Letters, 262, 21-36.

464 Luais B. (2012) Germanium chemistry and MC-ICPMS isotopic measurements of Fe-Ni, Zn 465 alloys and silicate matrices: Insights into deep Earth processes. Chemical Geology, 334, $466 \quad 295-311$.

467 Liu Y., Diwu C., Zhao Y., Liu X., Yuan H., and Wang J. (2014) Determination of trace and 468 rare-earth elements in Chinese soil and clay reference materials by ICP-MS. Chinese 469 Journal of Geochemistry,33, 095-102.

470 Lugolobi F., Kurtz A.C. and Derry L.A. (2010) Germanium-silicon fractionation in a tropical, 471 granitic weathering environment. Geochimica et Cosmochimica Acta, 74, 1294-1308.

472 Makishima A. and Nakamura E. (2009) Determination of Ge, As, Se and Te in Silicate 473 Samples Using Isotope Dilution-Internal Standardisation Octopole Reaction Cell ICP474 QMS by Normal Sample Nebulisation. Geostandards and Geoanalytical Research, 33, $475 \quad 369-384$. 
476 Mc Mahon M., Regan F. and Hughes H. (2006) The determination of total germanium in real

477 food samples including Chinese herbal remedies using graphite furnace atomic

478 absorption spectroscopy. Food Chemistry, 97, 411-417.

479 Mortlock R.A. and Froelich P.N. (1996) Determination of germanium by isotope dilution480 hydride generation inductively coupled plasma mass spectrometry. Analytica Chimica $481 \quad$ Acta, 332, 277-284.

482 Mortlock R. A., Froelich P. N., Feely R. A., Massoth G. J., Butterfield D. A., and Lupton J. E. 483 (1993) Silica and germanium in Pacific-ocean hydrothermal vents and plumes. Earth and $484 \quad$ Planetary Science Letters, 119, 365-378.

485 Opfergelt S., Cardinal D., André L., Delvigne C., Bremond L. and Delvaux B. (2010)

486 Variations of $\delta^{30} \mathrm{Si}$ and $\mathrm{Ge} / \mathrm{Si}$ with weathering and biogenic input in tropical basaltic ash 487 soils under monoculture. Geochimica et Cosmochimica Acta, 74, 225-240.

488 Pokrovski G.S., and Schott J. (1998) Thermodynamic properties of aqueous Ge (IV)

489 hydroxide complexes from 25 to $350^{\circ} \mathrm{C}$ : Implications for the behavior of germanium and 490 the Ge/Si ratio in hydrothermal fluids. Geochimica et Cosmochimica Acta, 62, 1631$491 \quad 1642$.

492 Qi H.-W., Rouxel O., Hu R.-Z., Bi X.-W., Wen H.-J. (2011) Germanium isotopic systematics 493 in Ge-rich coal from the Lincang Ge deposit, Yunnan, Southwestern China. Chemical $494 \quad$ Geology, 286, 252-265.

495 Rouxel O., and Luais B. (2017) Germanium isotope geochemistry. Reviews in Mineralogy 496 and Geochemistry, 82, 601-656.

497 Rosenberg E. (2009) Germanium: environmental occurrence, importance and speciation. 498 Reviews in Environmental Science Bio/Technology, 8, 29-57. 
499 Scribner A. M., Kurtz A. C., and Chadwick O. A. (2006) Germanium sequestration by soil:

500 Targeting the roles of secondary clays and Fe-oxyhydroxides. Earth and Planetary

$501 \quad$ Science Letters, 243, 760-770.

502 Shen B., Lee C.-T. A., Xiao S. (2011) Germanium/silica ratios in diagenetic chert nodules

503 from the Ediacaran Doushantuo Formation, South China. Chemical Geology, 280, 323-

$504 \quad 335$.

505 Soylak M. and Yigit S. (2015) Preconcentration-separation of germanium at ultra trace levels 506 on polysulfone membrane filter and its determination by spectrophotometry. Journal of $507 \quad$ Industrial and Engineering Chemistry, 24, 322-325.

508 Sutton J., Ellwood M.J., Maher W.A., and Croot P.L. (2010) Oceanic distribution of inorganic 509 germanium relative to silicon: Germanium discrimination by diatoms. Global

510 Biogeochemical Cycles, 24, GB2017, doi:10.1029/2009GB003689.

511 Tribovillard N., Bout-Roumazeilles V., Riboulleau A., Baudin F., Danelian T. and Riquier L.

512 (2011) Transfer of germanium to marine sediments: Insights from its accumulation in 513 radiolarites and authigenic capture under reducing conditions. Some examples through 514 geological ages. Chemical Geology, 282,120-130.

515 Wang Y., Gu T., Wang X., Gao Y.-S., Jochum K.P., Müller W.E.G. (2013) Practical 516 handbook of reference materials for geoanalysis, second, Geological Publishing House, 517 Beijing.

518 Wiche O., Zertani V., Hentschel W., Achtzige R. and Midula P. (2017) Germanium and rare 519 earth elements in topsoil and soil-grown plants on different land use types in the mining 520 area of Freiberg (Germany). Journal Geochemical Exploration, 175, 120-129. 
1

2

3

4

5

6

7

8

9

$10 \quad 524$

521 Wheat C.G. and McManus J. (2005) The potential role of ridge-flank hydrothermal systems

522 on oceanic germanium and silicon balances. Geochimica et Cosmochimica Acta, 69, $523 \quad 2021-2029$. 